\title{
Use of fly ash from fluidized bed boilers in clinker-slag-ash based binders
}

\author{
Elżbieta Janowska-Renkas*, and Jolanta Kowalska \\ Department of Engineering Building Materials, Faculty of Civil Engineering, Opole University \\ of Technology, Katowicka 48, 45-061 Opole, Poland
}

\begin{abstract}
The study presents the state of knowledge regarding physical and chemical properties, as well as trends for application of fly ashes from combustion in fluidized bed boilers in building materials. Clinker - slag ash based binders were tested that contained up to 40 mass \% of fly ashes from combustion in fluidized bed boilers. It was demonstrated that fluidized bed combustion fly ashes (FBC fly ash), apart from granular blast furnace slag, could be the ingredient of low clinker Portland cements (ca. $20 \%$ by mass). These cements, compared to CEM I Portland cement, have higher water demand and durability in the corrosive environment, and a lower compressive strength value. Based on test results of binders with various content of blast furnace slag and fly ash, the clinker - slag - ash based binder was singled out, which demonstrated the higher durability in the corrosive environment. It was found that production of clinker - slag - ash based binders was possible in the strength class 32.5 even with $30 \%$ by mass of FBC fly ash content.
\end{abstract}

\section{Introduction}

A contemporary cement industry is formed by actions aiming at reduction of $\mathrm{CO}_{2}$ emissions, saving of natural resources, reduced outlays, on energy used, etc. [1]. One of more significant trends for changes is application of mineral additives as the ingredient of cement for general purposes.

Reduction of Portland clinker content in the cement, and thus application of a larger quantity of non-clinker based ingredients, becomes a part of a sustainable development strategy [2]. The most commonly used mineral additives to cement are: silica fly ash, granular blast furnace slag and the limestone [3].

Fly ashes coming from coal combustion in fluidized bed boilers are a continuously growing group of combustion process by-products [1-7]. It mainly results from the increasing number of this type of furnaces, due to necessity to reduce $\mathrm{SO}_{2}$ and nitrogen oxides emission to air. Main phases of fly ashes from the fluidized bed combustion are dehydrated minerals that form a waste rock if a primeval character, unreacted sorbent $\left(\mathrm{CaCO}_{3}\right)$, free $\mathrm{CaO}$ and anhydrite [1-6]. The low temperature of fuels combustion in fluidized bed boilers (800 $900^{\circ} \mathrm{C}$ ) causes that no liquid phase occurs in the bed, as well as no mullite and of glazed, round forms of ash grains [1-7].

\footnotetext{
${ }^{*}$ Corresponding author: e.janowska_renkas@interia.eu
} 
Clayey minerals, which are the main ingredient of $\mathrm{FBC}$ ashes, in temperature of $850^{\circ} \mathrm{C}$ undergo hydratation and form a dehydrated aluminium silicate substance with much higher pozzolanic activity than conventional fly ashes [1-7]. FBC fly ashes, contrary to ashes formed in traditional furnaces, contain irregular grains of high fineness and constituents which undergo hydratation, demonstrating binding properties [1-6].

A characteristic feature of FBC fly ashes is their fineness and thus the high specific surface area. A main factor, which has the impact on diversity of the particle size distribution, is a type of the plant and its operating parameters. Basic properties of FBC fly ashes are formed by: a type and a method of fuel combustion, a type of sorbent used and a type of fluidized bed boiler design [3].

The main threat resulting from FBC fly ashes application in concretes, is the calcium sulphate $\mathrm{CaSO}_{4}$, present in ashes, which may cause formation of delayed ettringite and destruction of the concrete [1-6]. Therefore, the content of sulphates in FBC fly ashes should be monitored when they are used in cement materials. Reactions, which occur during cement hydratation with FBC fly ashes, are complex and they are still a subject of research, and possibilities of their application in the cement and concrete materials have been presented in numerous studies $[1-6,9,12]$.

Currently the main issue is the management of FBC fly ashes, which do not meet the standard [16], regarding possibility of mineral additives application to the cement $[3,5]$.

Tests of FBC fly ashes carried out so far demonstrate that they may be used as the mineral additive to cement, which shows both pozzolanic and hydraulic properties. On the other hand, due to presence of calcium sulphate in their composition, they may be used as a time controller for cement binding process $[3,5,12]$. In recent years a few studies have been published, where authors demonstrate that the total replacement of general purpose cement with the ash - slag binder, allows to get materials with increased durability $[1-6,9,12]$. According to some researchers, the quantity of FBC fly ashes introduced into cement may reach from $15 \%$ to $30 \%$ by mass. [1-6, 12$]$.

The objective of the study was to determine composition of the clinker - slag - ash based binder, which allowed to get higher durability pastes with possible largest content of fly ashes from fluidized bed combustion (FBC fly ash).

\section{Materials for testing}

The clinker - slag - ash based mortars were used for testing, with different composition, which had the content of blast furnace slag and fly ashes from fluidized bed combustion (FBC fly ash) from $10 \%$ to $40 \%$ by mass. For comparison purposes, standard mortars were made of the Portland cement - CEM I 42,5 R. Standard sand that meets requirements of PN-EN 196-1:2016 was used in mortars.

Phase composition of FBC fly ashes is presented in Fig. 1 The following phases were identified in a diffractogram: quartz, anhydrite, gehlenite, calcite, calcium oxide, portlandite, cristobalite, aluminium oxide, hematite, muscovite, farchildite, orthoclase [13].

The chemical composition and specific surface area was determined acc. to Blaine for Portland cement, clinker, blast furnace slag and fluidized bed combustion fly ashes (FBC fly ashes) are given in Table 1 [14]. Table 2 present composition of clinker - slag - ash mortars used for testing, in order to determine the most favourable composition of binders, for possibility of FBC fly ash management. The above was determined based on compressive strength test results of the aforementioned mortars after 28 days of curing in lab conditions. 


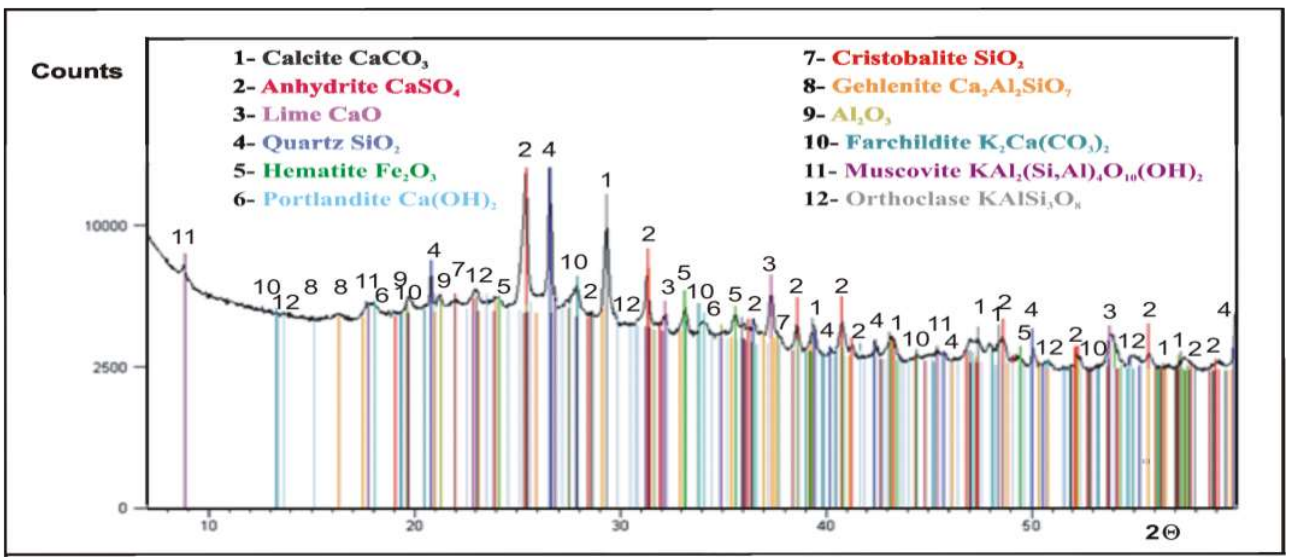

Fig.1. The XRD pat tern of fly ash from fluidized bed boilers [13].

Table 1. Chemical composition (\% by weight) [14].

\begin{tabular}{|c|c|c|c|c|c|c|c|c|c|}
\hline \multirow{2}{*}{ Sample } & Blaine & \multicolumn{8}{|c|}{ Chemical composition (\%) } \\
\cline { 3 - 10 } & $\left(\mathbf{m}^{2} / \mathbf{k g}\right)$ & $\mathbf{S i O}_{2}$ & $\mathbf{A l}_{\mathbf{2}} \mathbf{O}_{\mathbf{3}}$ & $\mathbf{F e}_{\mathbf{2}} \mathbf{O}_{\mathbf{3}}$ & $\mathbf{C a O}$ & $\mathbf{M g O}$ & $\mathbf{K}_{2} \mathbf{O}$ & $\mathbf{N a}_{2} \mathbf{O}$ & $\mathbf{S O}_{\mathbf{3}}$ \\
\hline Cement & 400 & 19.79 & 5.76 & 2.98 & 62.28 & 1.71 & - & - & 2.62 \\
\hline Clinker & 280 & 19.8 & 7.16 & 3.18 & 65.10 & 1.63 & 1.10 & 0.20 & 0.91 \\
\hline Slag & 330 & 37.65 & 8.72 & 1.13 & 41.52 & 8.88 & - & - & 0.09 \\
\hline $\begin{array}{c}\text { FBC fly } \\
\text { ash }\end{array}$ & 830 & 39.26 & 29.37 & 3.79 & 12.04 & 1.79 & 1.01 & 1.49 & 3.13 \\
\hline
\end{tabular}

Table 2. The composition of the mortars.

\begin{tabular}{|c|c|c|c|c|c|c|c|c|c|c|c|c|}
\hline \multirow{2}{*}[\%]{} & \multicolumn{10}{|c|}{ Mix } \\
\cline { 2 - 14 } & S1 & S2 & S3 & S4 & S5 & S6 & S7 & S8 & S9 & S10 & S11 & S12 \\
\hline Cement & 100 & - & - & - & - & - & - & - & - & - & - & - \\
\hline Clinker & - & 80 & 70 & 70 & 60 & 60 & 60 & 50 & 50 & 50 & 40 & 20 \\
\hline Slag & - & 10 & 10 & 20 & 10 & 20 & 30 & 20 & 30 & 40 & 30 & 40 \\
\hline $\begin{array}{c}\text { FBC fly } \\
\text { ash }\end{array}$ & - & 10 & 20 & 10 & 30 & 20 & 10 & 30 & 20 & 10 & 30 & 40 \\
\hline
\end{tabular}

\section{Test methods}

\subsection{Consistency of mortars}

The cement and clinker - slag - ash mortars were prepared, while keeping the identical consistency $(5 \pm 0.5 \mathrm{~cm}$ acc. to cone penetrometer method) that corresponded the consistency of the standard mortar made of CEM I 42,5 R cement (acc. to PN-EN PN-EN 196-1).

\subsection{Pozzolanic activity acc. to PN-EN 450-1:2009}

The pozzolanic activity of FBC fly ashes was determined for mortars containing 25 mass $\%$ of FBC fly ashes in the cement. The pozzolanic activity index was determined as a ratio of compressive strength of mortars of cement binders containing FBC fly ashes to the strength of the standard mortar. According to PN-EN 450-1 standard, it is required that the pozzolanic activity index after 28 days of curing reached the value of at least $75 \%$ compressive strength of the standard mortar, and after 90 days $-85 \%$ of this strength. 


\subsection{Compressive strength}

Tests of compressive strength after 2, 7, 28 and 90 days of curing were conducted in line with recommendations of PN-EN 196-1 standard on test pieces with dimensions $40 \times 40 \times 160$ $\mathrm{cm}$. After 24 hours, test pieces were taken out of the mould and until testing they were stored in lab conditions in temperature $20 \pm 2{ }^{\circ} \mathrm{C}$. Then after 28 days, mortars which demonstrated the highest compressive strength and the highest content of FBC fly ashes were subject to tests, which aimed at determination of mortars durability.

\subsection{Particle Size Distribution}

Particle size distribution tests of the cement and clinker - slag - ash binders were conducted by means of the Mastersizer 3000 laser particle size analyzer - with a wet method using isopropyl alcohol as a dispersant. Before testing, samples of binders were subject to a 3-hour homogenization in a ball mill.

\subsection{Durability of mortars - linear changes}

Tests of durability for cement and clinker - slag - ash mortars were conducted by means of the Graff-Kauffman apparatus, as a measurement of samples expansion kept in $\mathrm{Na}_{2} \mathrm{SO}_{4}$ solution according to PN-B-19707:2013-10 standard. Test pieces with dimensions $20 \mathrm{x} 20 \mathrm{x}$ $160 \mathrm{~mm}$ were prepared in moulds divided into six compartments, where elements for measurement of linear changes had been placed earlier. After a lapse of $24 \mathrm{~h}$, test pieces were taken out of the mould and placed in vessels with distilled water for a period of 28 days. Then samples were put into $\mathrm{Na}_{2} \mathrm{SO}_{4}$ solution of concentration c $\left(\mathrm{SO}_{4}{ }^{2-}\right)=16.0 \pm 0.5 \mathrm{~g} / \mathrm{l}$ and to the reference (test) solution (distilled $\mathrm{H}_{2} \mathrm{O}$ ). Test pieces were stored in lab conditions and every 4 weeks for a period of 12 months - measurements of mortars linear changes were performed. The solution of sodium sulphate was exchanged every 4 weeks. Linear changes of samples kept in $\mathrm{Na}_{2} \mathrm{SO}_{4}$ solution and distilled water were calculated in accordance with requirements of PN-B-19707:2013 standard, while monitoring the expansion which should not be higher than $0.5 \%$ per year.

\subsection{Porosity of mortars}

Porosity testing of mortars after 2, 7, 28 and 90 days of curing was conducted by means of a mercury porosimeter - PoreMaster 60 acc. to PN-EN 196-1. For testing samples were cut out of diameter $5 \mathrm{~mm}$ and height ca. $10 \mathrm{~mm}$. Then test pieces were dried to constant mass in temperature $60^{\circ} \mathrm{C}$ and subject to testing within a pressure range from 1 to $400 \mathrm{MPa}$. Test results were presented in a form of volumetric content of pores and distribution curves of pore sizes within a range from $0.0035 \mu \mathrm{m}$ to $1000 \mu \mathrm{m}$.

\section{Test results}

\subsection{Consistency of mortars}

Results of consistency tests for clinker - slag - ash mortars determined by the cone penetrometer method (cone slump) are presented in Table 3. Analysis of consistency test results demonstrated that with the increase of FBC fly ashes (from $10 \%$ to $40 \%$ by mass), the water demand of clinker - slag - ash based binders rose. Thus, in order to obtain the identical consistency of mortars, a higher water demand was observed from $\mathrm{w} / \mathrm{b}=0.53$ - for $\mathrm{S} 4$ binder 
containing 10 mass $\%$ of FBC fly ashes to $\mathrm{w} / \mathrm{b}=0.76$ - for $\mathrm{S} 12$ binder containing 40 mass $\%$ of FBC fly ashes. The opposite relation, demonstrating the lower water demand, was observed along with increased content of blast furnace slag in clinker - slag - ash based binder (Table 3).

Table 3. Results of investigations of consistency of cement and clinker - slag - fly ash in the fresh mortars.

\begin{tabular}{|c|c|c|c|c|c|c|c|c|c|c|c|c|}
\hline \multirow{2}{*}{ Type } & \multicolumn{10}{|c|}{ Consistency of fresh mortars } \\
\cline { 2 - 13 } & S1 & S2 & S3 & S4 & S5 & S6 & S7 & S8 & S9 & S10 & S11 & S12 \\
\hline w/b & 0.48 & 0.58 & 0.56 & 0.53 & 0.62 & 0.58 & 0.54 & 0.60 & 0.58 & 0.53 & 0.70 & 0.76 \\
\hline $\begin{array}{c}\text { Cone slump } \\
{[\mathrm{cm}]}\end{array}$ & 5.2 & 5.0 & 4.6 & 5.0 & 5.1 & 5.5 & 5.0 & 5.1 & 5.2 & 5.1 & 5.3 & 5.4 \\
\hline
\end{tabular}

\subsection{Pozzolanic activity}

Based on pozzolanic activity indices determined (Table 4) it was found that FBC fly ashes used for tests, demonstrated the pozzolanic activity of $83.4 \%$ (after 28 days of testing) and $82.4 \%$ ((after 90 days of testing).

Table 4. Pozzolanic activity index.

\begin{tabular}{|c|c|c|c|c|c|}
\hline \multirow{2}{*}{ Type of mortar } & \multicolumn{5}{|c|}{ Compressive strength [MPa] } \\
\cline { 2 - 6 } & $\begin{array}{c}\mathbf{2} \\
\text { days }\end{array}$ & $\begin{array}{c}\mathbf{7} \\
\text { days }\end{array}$ & $\mathbf{1 4}$ days & $\mathbf{2 8}$ days & 90 days \\
\hline CEM I 42,5 R & 18.0 & 36.3 & 42.0 & 49.7 & 57.0 \\
\hline CEM I 42,5 R + 25\% FBC fly ash & 13.8 & 27.6 & 36.4 & 41.5 & 46.9 \\
\hline Pozzolanic activity index [\%] & 76.6 & 76.0 & 86.5 & 83.4 & 82.4 \\
\hline Requirements of the standard [\%] & - & - & - & 75.0 & 85.0 \\
\hline
\end{tabular}

It indicates that the pozzolanic activity of ashes used after 28 days of testing is higher by ca. $8 \%$ from the activity index determined by the standard, and after 90 days of testing it demonstrates a slight (by ca. 2.6\%) drop of activity compared to standard recommendations (85\%) (Table 4).

\subsection{Compressive strength}

Results of compressive strength tests for clinker - slag - ash based binders and cement binders (Fig. 2a and 2b) demonstrated that introduction of the blast furnace slag and FBC fly ashes in amount up to 40 mass\% to Portland clinker allowed to achieve the binder corresponding to the cement equal to 32.5 .

As it could be expected, the highest compressive strength after 28 days of curing (43.7 MPa) was achieved by S4 mortar containing one of the highest percentage of Portland clinker $(70 \%$ clinker $+20 \%$ slag $+10 \%$ FBC fly ash). On the other hand, among mortars based on the binder with the lowest clinker content up to $60 \%$ by mass, in favour of increased content of blast furnace slag and FBC fly ash, the highest strength values were demonstrated by: S5 mortar $(60 \%$ clinker $+10 \%$ slag $+30 \%$ FBC fly ash $)$ and S6 mortar $(60 \%$ clinker $+20 \%$ slag $+20 \%$ FBC fly ash) $-37.0 \mathrm{MPa}$ and 40.1 MPa respectively. The above results allowed selection of those binders for further testing, to determine their durability, including in the corrosive environment. 


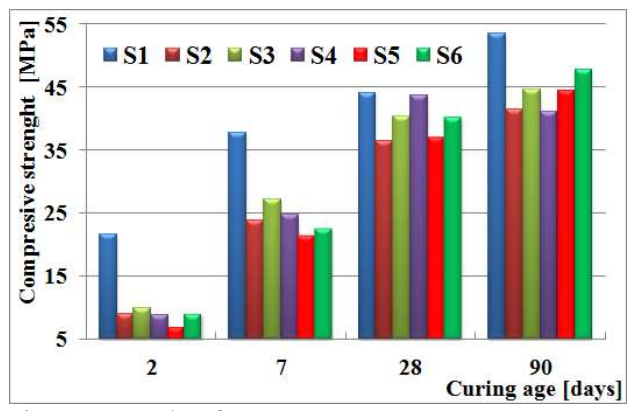

a) mortars S1-S6

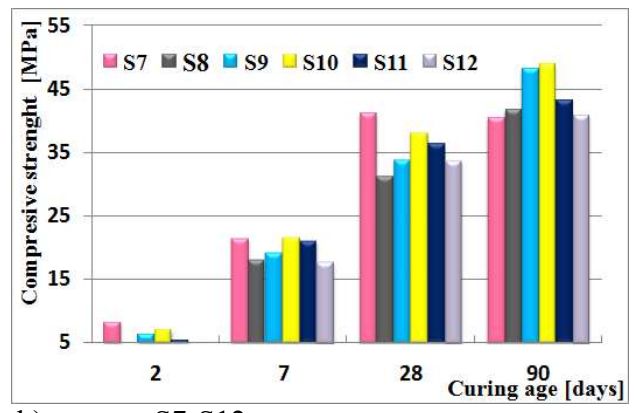

b) mortars S7-S12

Fig.2. Bending and compressive strength of cement and clinker - slag - fly ash mortars after 2, 7, 28 and 90 days.

\subsection{Particle Size Distribution}

Fig. 3 presents a particle size distribution in the Portland cement - CEM I 42,5 R and in binders: S5 (60\% clinker $+10 \%$ slag $+30 \%$ FBC fly ash) and S6 (60 \% clinker $+20 \%$ slag $+20 \%$ FBC fly ash).

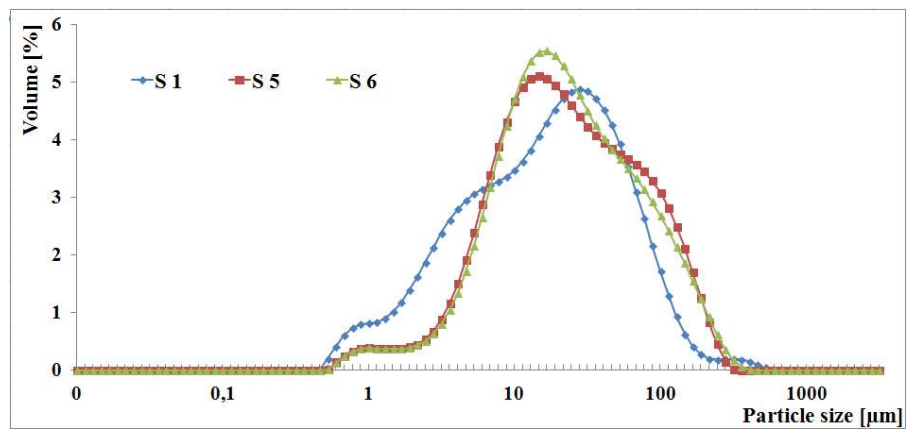

Fig 3. Particle size distribution of binders tested.

Table 5 presents percentage content of particle sizes in binders tested. It was found that introduction of mineral additives in a form of blast furnace slags and FBC fly ashes in place of the cement, had the impact on a change of particle size distribution of binders.

Table 5. Particle size distribution of binders tested.

\begin{tabular}{|c|c|c|c|c|}
\hline \multirow{2}{*}{$\begin{array}{c}\text { Type of } \\
\text { binder }\end{array}$} & \multicolumn{4}{|c|}{ Particle size distribution [\%] } \\
\cline { 2 - 5 } & $<\mathbf{1 0} \mathbf{\mu m}$ & $\begin{array}{c}\mathbf{1 0}-\mathbf{5 0} \\
\boldsymbol{\mu m}\end{array}$ & $\begin{array}{c}\mathbf{5 0}-\mathbf{1 0 0} \\
\boldsymbol{\mu m}\end{array}$ & $\begin{array}{c}>\mathbf{1 0 0} \\
\boldsymbol{\mu m}\end{array}$ \\
\hline S 1 & 34.79 & 45.94 & 14.06 & 5.21 \\
\hline S 5 & 23.30 & 48.50 & 16.11 & 12.09 \\
\hline S 6 & 21.92 & 51.64 & 15.07 & 11.37 \\
\hline
\end{tabular}

That leads to over two-time rise of fraction above $100 \mu \mathrm{m}$ and reduction of fraction below $10 \mu \mathrm{m}$ by ca. $30 \%$ in clinker - slag - ash based binders compared to the cement based binder. This indicates that reduction of fine fractions in S5 and S6 binders may have the influence on durability of mortars. 


\subsection{Durability of mortars}

The impact of corrosive environment on durability of mortars was demonstrated based on tests of mortars linear changes (Fig. 4). Analysis of obtained test results indicates that addition of fly ashes from fluidized bed combustion (FBC fly ash) has the influence on inhibit of sulphate aggression of clinker - slag - ash based mortars, which was demonstrated by reduced linear dimensions of test pieces with the content of those ashes, compared to samples of pure cement. The test (reference) mortar made of CEM I 42,5 R cement underwent degradation after being kept for 7 months in the aggressive environment of the sulphuric acid, which indicated exceeding of the expansion criterion amounted to over $0.5 \%$. As it is known, a product of the cement hydratation is a portlandite, which due to a high chemical activity dissolves when reacting with the acid, which leads to weakening of the microstructure of mortars, and thus their faster destruction []. It may be prevented by introducing mineral additives to the cement, i.e. blast furnace slags or fluidized bed combustion fly ashes.

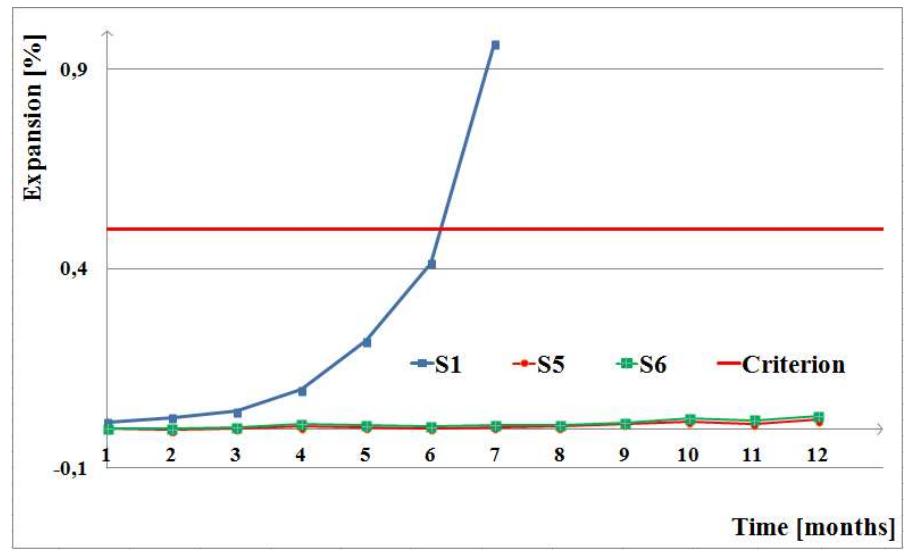

Fig. 4. Linear changes of cement and clinker - slag - ash based mortars in $\mathrm{Na}_{2} \mathrm{SO}_{4}$ environment.

Mortars made under the study of the binder containing $60 \%$ clinker $+10 \%$ slag $+30 \%$ FBC fly ash (S5) and 60\% clinker $+20 \%$ slag $+20 \%$ FBC fly ash (S6) for the entire testing period (12 months) demonstrated expansion on a level no lower than permitted $0.5 \%$. S5 and S6 mortars showed the increased resistance to sulphate corrosion compared to the test (reference) mortar (S1), which can be explained by a content of mineral additives (blast furnace slags and FBC fly ashes) in those mortars composition.

Increased corrosion resistance of clinker - slag - ash based mortars tested results most likely from formation of additional products of hydratation coming from FBC fly ashes and blast furnace slags used. Anhydrite coming from FBC fly ashes may be the slag activator, and when bound with aluminium phases, it reduces the threat associated with potential occurrence of the sulphate corrosion risk. Simultaneous application of blast furnace slags and FBC fly ashes allows for additional sealing of the cement matrix, which is confirmed by authors of work [3].

\subsection{Porosity}

Porosity of mortars was tested after 7, 14, 28 and 90 days of curing in water environment. Pore size dimensions was determined within a range from 0.0035 to $200 \mu \mathrm{m}$. Table 5 presents percentage of pores in S1 cement mortar and in mortars: S5 (60\% clinker $+10 \% \mathrm{slag}+30 \%$ 
FBC fly ash) and S6 (60\% clinker $+20 \%$ slag $+20 \%$ FBC fly ash). Figures 5 a $-5 \mathrm{~d}-$ present differential curves of pore volume distribution as a function of pore diameters.

Table 5. Percentage content of pores in mortars cured in water for 2, 7, 14 and 90 days.

\begin{tabular}{|c|c|c|c|c|c|c|c|}
\hline \multirow{2}{*}{ Day } & \multirow{2}{*}{$\begin{array}{c}\text { Type } \\
\text { of } \\
\text { binder }\end{array}$} & \multirow{2}{*}{$\begin{array}{c}\text { Total } \\
\text { porosity } \\
{[\%]}\end{array}$} & \multicolumn{5}{|c|}{ Percentage of pores [\%] } \\
\hline & & & $\begin{array}{l}<\mathbf{5 0} \\
\mathbf{n m}\end{array}$ & $\begin{array}{c}50-200 \\
\mathrm{~nm}\end{array}$ & $\begin{array}{c}200-2000 \\
\mathrm{~nm}\end{array}$ & $\begin{array}{c}2000-20000 \\
\mathrm{~nm}\end{array}$ & $\begin{array}{c}<20000 \\
\mathbf{n m}\end{array}$ \\
\hline \multirow{3}{*}{7} & S 1 & 16.27 & 38.3 & 47.6 & 7.7 & 0.8 & 5.3 \\
\hline & S 5 & 24.07 & 42.5 & 23.3 & 30.6 & 0.6 & 2.9 \\
\hline & S 6 & 20.88 & 48.5 & 34.4 & 14.6 & 0.5 & 1.9 \\
\hline \multirow{3}{*}{14} & S 1 & 15.74 & 46.5 & 43.5 & 5.9 & 1.4 & 2.9 \\
\hline & S 5 & 20.32 & 54.4 & 33.9 & 7.8 & 0.7 & 3.1 \\
\hline & S 6 & 19.69 & 50.6 & 32.4 & 12.2 & 1.5 & 3.3 \\
\hline \multirow{3}{*}{28} & S 1 & 13.51 & 49.5 & 40.5 & 4.5 & 0.3 & 5.4 \\
\hline & S 5 & 20.01 & 70.2 & 22.3 & 3.4 & 0.7 & 3.5 \\
\hline & S 6 & 18.16 & 59.0 & 33.2 & 5.4 & 0.7 & 1.8 \\
\hline \multirow{3}{*}{90} & S 1 & 13.19 & 46.5 & 41.0 & 8.3 & 0.8 & 2.6 \\
\hline & S 5 & 20.26 & 67.6 & 17.9 & 10.6 & 1.0 & 2.4 \\
\hline & S 6 & 19.34 & 62.8 & 22.6 & 8.4 & 1.4 & 4.8 \\
\hline
\end{tabular}

According to [11], formation of pores in cement mortars has the impact on e.g. on: composition of mortars, w/c ratio, a method of mixing and compacting, as well as conditions of mortars curing.

Results of porosity testing (Table 5, Fig. 5a-d) demonstrated that the hardened cement mortar with CEM I 42,5 R had the lowest total porosity in the entire curing period of test pieces in water (from 7 to 90 days of testing).

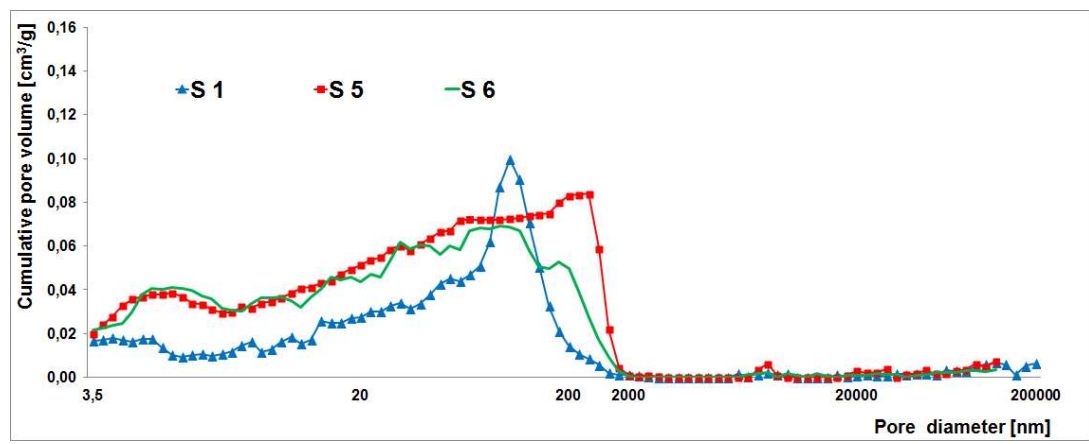

a) 7 days 


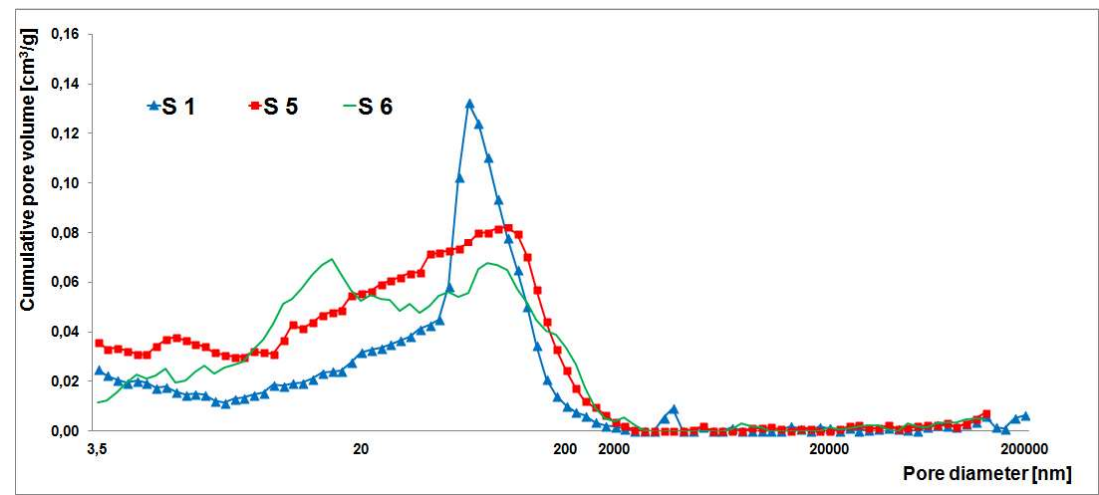

b) 14 days

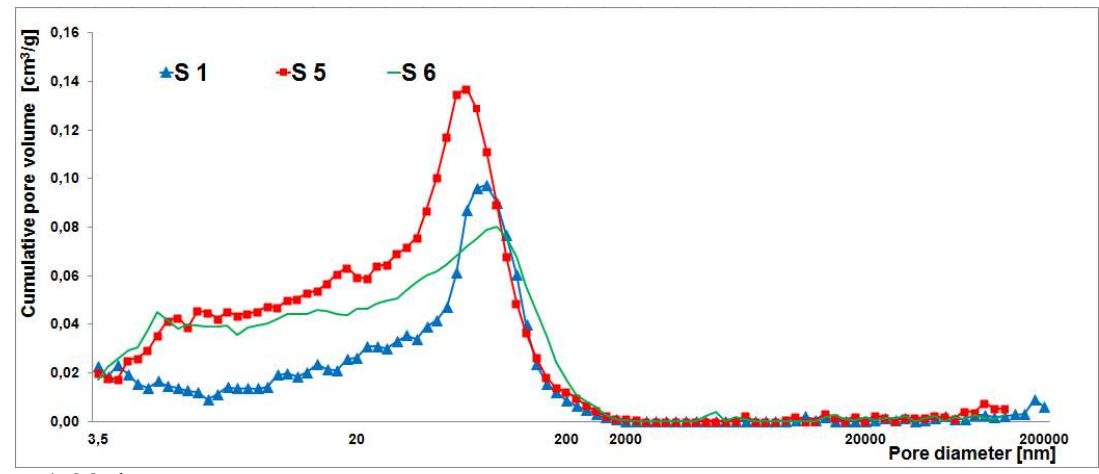

c) 28 days

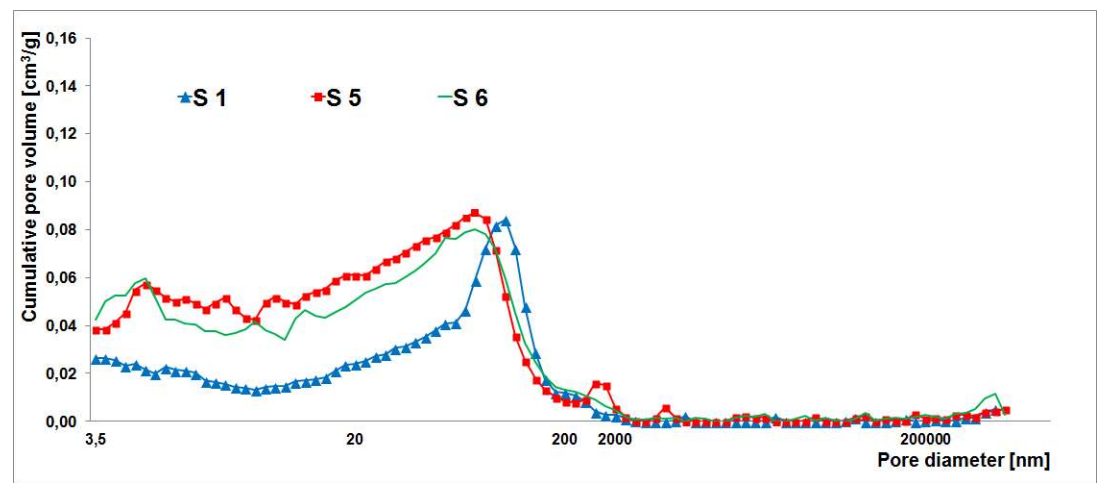

d) 90 days

Fig. 5. Differential curves of pore volume distribution as a function of pore diameter.

Its porosity gets lower in time from $16.27 \%$ after 7 days to $13.19 \%$ after 90 days of testing. Analogical relation with a tendency to reduction of total porosity in time (from 14 to 90 days) was demonstrated for clinker - slag - ash based mortars - S5 and S6. Whereas the total porosity of those mortars was higher than porosity observed for S1 cement based mortar, showing a difference of ca. $4 \%$ after 7 days of testing and ca. $1-2 \%$ in the period from 14 to 90 days of samples curing. It indicates a relation between the FBC fly ash content in mortars to the total content of pores. And thus in case of S5 mortar containing 30 mass $\%$ of FBC fly ashes, the highest total porosity was found. On the other hand, reduction of ashes to 20 mass $\%$ in S6 mortar, regardless of testing time, had a beneficial impact on porosity reduction. 
These results may indicate limited possibility of FBC fly ashes use in cement materials in place of the cement, depending on their content, which is also emphasized by authors of work $[1-6,9,12-14]$ by explaining that with a large specific surface area connected with high open porosity of FBC ashes, which are the effect of conditions in which these ashes are formed.

The thorough analysis of pore content showed that clinker - slag - ash based mortars (S5 and S6) are distinguished with higher content of mezopores $(<50 \mathrm{~nm})$. It was demonstrated that the content of mezopores in S5 and S6 mortars was higher than in case of S1 mortar based on pure cement. At the same time it was found that presence of blast furnace slags and FBC fly ashes had influence on reduction of quantity of macropores $(>50 \mathrm{~nm})$, and the higher content of FBC fly ashes was in the binder, the lower quantity of macropores was.

\section{Conclusions}

It was found that presence of fly ashes from fluidized bed combustion in clinker - slag - ash based mortars had higher water demand than in case of cement based mortars. The higher addition of FBC ashes, the higher water demand of mortars is. A reverse relation was observed with the increase of blast furnace slags in the clinker - slag - ash binder, from $10 \%$ to $40 \%$ by mass. The higher content of slags in the binder, the lower water demand of mortars is.

It was found that the content of FBC fly ashes in the binder should not exceed $30 \%$ by mass, due to deterioration of physical parameters of mortars with the increased percentage of this additive in the clinker - slag - ash binder. Production of clinker - slag - ash binders is possible in strength class 32.5 .

It was demonstrated that presence of FBC fly ashes and blast furnace slags in the clinker - slag - ash binders affected reduction of mezopores quantity $(<50 \mathrm{~nm})$ at the expense of reduced quantity of macropores $(>50 \mathrm{~nm})$. It has a beneficial effect on increased corrosion resistance of those mortars.

Obtained results of testing confirm possibility of FBC fly ash management by its use in clinker - slag - ash binders in quantity up to $30 \%$ by mass, which was confirmed by results of compressive strength tests and the smallest linear changes observed in the corrosive environment $\left(\mathrm{SO}_{4}{ }^{2-}\right)$.

\section{References}

1. R. Bartnik, Conference - "XVII Innowacje w Zarządzaniu i Inżynierii Produkcji”, (2014) (in Polish)

2. J. Kabała, B. Brzozowski, W. Rozszczynialski, J. Małolepszy, "Własności i zastosowanie ubocznych produktów spalania węgla w kotłach fluidalnych", XIII International Conference "Popioły z energetyki", 121-142 (2006) (in Polish)

3. A.M. Brandt, praca zbiorowa, "Zastosowanie popiołów lotnych z kotłów fluidalnych w betonach konstrukcyjnych", 379-391 (2010) (in Polish)

4. M. Gawlicki, W. Roszczynialski, "Ocena możliwości wykorzystania w przemyśle cementowym ubocznych produktów spalania powstających w kotłach fluidalnych" IV Conference MATBUD'2003 (2003) (in Polish)

5. K. Rajczyk, "Popioły lotne z kotłów fluidlanych i możliwości ich uszlachetniania" Wydawnictwo Instytut Śląski (2012) (in Polish)

6. A. Łagosz, J. Małolepszy, J. Śliwiński, T. Tracz, "Wykorzystanie popiołów fluidalnych jako dodatku mineralnego do betonów”, Conference - „Dni Betonu”, 553-566 (2008) (in Polish) 
7. H. Maenami, N. Isu, E.H. Ishida, T. Mitsuda, "Electron microscopy and phase analysis of fly ash from pressurized fluidized bed combustion" Cement and Concrete Research, 34, $781-788$ (2004)

8. I. Iribarne, A. Iribarne, J. Blondin, E.J. Anthony, "Hydration of combustion ashes a chemical and physical study", Fuel, 80, 773-784 (2001)

9. M. Chi, "Synthesis and characterization of mortars with circulating fluidized bed combustion fly ash and ground granulated blast-furnace slag", Construction and Building Materials, 123, 565-573 (2016)

10. S. Diamond, "Delayed ettringite formation - processes and problems", Cement and Concrete Research, 18, 205-215 (1996)

11. A.M. Brandt, "Diagnostyka betonu na podstawie badania struktury", Przegląd budowlany, 10, 53-61 (2011) (in Polish)

12. W. Zhang, H. Choi, T. Sagawa, Y. Hama, "Compressive strength development and durability of an environmental load-reduction material manufactured using circulating fluidized bed ash blast - furnace slag", Construction and Building Materials, $146,102-113$ (2017)

13. S. Grzeszczyk, E. Janowska-Renkas, "Wpływ popiołów lotnych z kotłów fluidalnych na właściwości reologiczne zaczynów cementowych”, Inżynieria i Budownictwo, 11, 63-66 (2016) (in Polish)

14. J. Kowalska, S. Grzeszczyk, "Wpływ popiołów lotnych z kotłów fluidalnych na wybrane właściwości spoiw i zapraw klinkierowych oraz cementowych", Wybrane Zagadnienia Inżynierii Środowiska w Budownictwie, 197-206 (2014) (in Polish)

15. PN-EN 197-1:2012 Cement- Part 1: Composition, specifications and conformity criteria for common cements

16. PN-EN 450-2012 Fly ash for concrete - Part 1: Definition, specifications and conformity criteria

17. PN-EN-196-1:2016 Methods of testing cement- Part 1: Determination of strength

18. PN-B-19707:2013 Cement. Special cement. Composition, requirements and compliance criteria 